\section{Fluorinated steroids}

TO THE EDITOR British Fournal of Ophthalmology

SIR, Many ophthalmologists must have heard or read by now of the adverse effect on the skin of the prolonged use of fluorinated steroids, such as betamethasone, fluocinolone, and fluocortolone 2I-hexanoate. It has been said that the fluorine present induces neovascularization and dilatation (telangiectasia) and ruptures the dermal collagen and follicular epithelium. These adverse changes are reversed by using hydrocortisone. Despite this finding which originated in 1969 I do not know of any statistically significant account of a similar effect on the eye. In two cases of postherpetic disciform keratitis in which drops of betamethasone were prescribed for a year, and in one case where the same drops had been prescribed daily for two years by a general practitioner for conjunctivitis sicca, I found many substantial dilated vessels in the corneal stroma asso- ciated with a highly irritable eye. There was no other pathological feature. On changing to drops of hydrocortisone I per cent, the symptoms were relieved and after one week most of the corneal blood vessels had become emptied.

Yours faithfully, F. C. RODGER

Princess Margaret Hospital,

Swindon,

Wiltshire

\section{References}

leyden, J. J., Thew, M., and kligman, A. M. (1974) Arch. Derm., I10, 619

KAIDBEY, K. H., and KLIGMAN, A. M. (1974) $\mathcal{F}$. Invest. Derm., 62, 3 I

SNEDDON, I. (1969) Brit. med. F., 1, 671

- (1972) Brit. 7. Derm., 87, 430

WEBER, G. (1972) Ibid., 86, 253

\title{
Aqueous humour lactic dehydrogenase isoenzymes in retinoblastoma
}

(Brit. F. Ophthal. (1975), 59, 268)

TO THE EDITOR British Fournal of Ophthalmology

SIR, Since our paper was published last May we have become aware of additional relevant information we wish to bring to your attention.

We have had the opportunity to study two patients in whom aqueous humour assays were at variance with our previously-reported findings. One patient, with histologically proven retinoblastoma, had a total aqueous humour lactic dehydrogenase (LDH) of $2303 \mathrm{iu} / 1$ and a ratio $\mathrm{LDH}_{5}: \mathrm{LDH}_{1}$ of only $\mathrm{I} \cdot 9$. The other patient, with bilateral, congenital non-rhegmatogenous retinal detachment and no retinoblastoma, had total aqueous humour LDH levels of 194 and 19 , and ratios $\mathrm{LDH}_{5}$ : $\mathrm{LDH}_{1}$ of 24 and 30 !

A recent paper by Swartz, Herbst, and Goldberg (1974) supported the original hypothesis of Dias, Senthe Shanmuganathan, and Rajaratnam (197I) that retinoblastoma was associated with a raised total aqueous humour $\mathrm{LDH}$, and they referred to a paper (Kaneko and Suzuki, 1972) in which the authors found (as we did) that, although the total aqueous humour LDH was inconsistently raised in retinoblastoma, in seven cases

\section{Corneal epithelial oedema}

\section{TO THE EDITOR British fournal of Ophthalmology}

SIR, Over many years some difficulty has been experienced during prolonged three-mirror examinations because corneal epithelial oedema tended to supervene after a few minutes. The solutions being used at this hospital were I, 2, or 3 per cent hydroxypropyl methyl cellulose (HPMC) in water with phenyl mercuric nitrate 0.002 per cent.

It occurred to us that due to the large size of the HPMC molecule, the osmotic effect of such a solution was almost identical to that of water, hence it was a likely cause of the epithelial oedema. it was associated with an elevated $\mathrm{LDH}_{3}$ isoenzyme (and to a lesser extent $\mathrm{LDH}_{2}$ and $\mathrm{LDH}_{4}$ fractions).

We believe that the aqueous humour $\mathrm{LDH}$ assay is currently a valuable diagnostic adjunct in the diagnosis of retinoblastoma, in that both an absolute elevation of the total aqueous humour $\mathrm{LDH}$ and a relative elevation of the slow isoenzyme fractions (that is, a 'shift to the right') appear to be suggestive but not diagnostic of retinoblastoma. We wish to encourage further experience with this test to resolve the inconsistencies in the literature, and to define the limits of reliability and the scope of application of this biochemical assay.

Yours faithfully,

PAUL E. ROMANO and JACK KABAK

Department of Ophthalmology,

Northwestern University Medical School,

Chicago, Illinois

\section{References}

DIAS, P. L. R., SENTHE SHANMUGANATHAN, S. S., and RAJARATNAM, M. (1971) Brit. F. Ophthal., 55, 130

KANEKO, A., and SUZUKI, H. (1972) Acta Soc. ophthal. fap., 76, 672 SWARTZ, M. S., HERBST, R. W., and GOLDBERG, M. F. (1974) Amer. $\mathcal{f}$.

Ophthal., 78, 612

Accordingly, HPMC was made up in 0.8 per cent sodium chloride instead of pure water.

This solution appears completely to have resolved the problem. The cornea remains crystal clear throughout the most prolonged examination. We thought this information would be of interest and value to readers.

Yours faithfully,

J. H. REDMOND SMITH and R. WATKINS

Moorfields Eye Hospital,

City Road,

London ECIV 2PD 